\title{
Coupled decadal variability of the North Atlantic Oscillation, regional rainfall and karst spring discharges in the Campania region (southern Italy)
}

\author{
P. De Vita, V. Allocca, F. Manna, and S. Fabbrocino \\ Dipartimento di Scienze della Terra - University of Naples “Federico II", Italy \\ Correspondence to: P. De Vita (padevita@unina.it) \\ Received: 23 November 2011 - Published in Hydrol. Earth Syst. Sci. Discuss.: 16 December 2011 \\ Revised: 16 April 2012 - Accepted: 24 April 2012 - Published: 11 May 2012
}

\begin{abstract}
Thus far, studies on climate change have focused mainly on the variability of the atmospheric and surface components of the hydrologic cycle, investigating the impact of this variability on the environment, especially with respect to the risks of desertification, droughts and floods. Conversely, the impacts of climate change on the recharge of aquifers and on the variability of groundwater flow have been less investigated, especially in Mediterranean karst areas whose water supply systems depend heavily upon groundwater exploitation.

In this paper, long-term climatic variability and its influence on groundwater recharge were analysed by examining decadal patterns of precipitation, air temperature and spring discharges in the Campania region (southern Italy), coupled with the North Atlantic Oscillation (NAO).

The time series of precipitation and air temperature were gathered over $90 \mathrm{yr}$, from 1921 to 2010 , using 18 rain gauges and 9 air temperature stations with the most continuous functioning. The time series of the winter NAO index and of the discharges of 3 karst springs, selected from those feeding the major aqueducts systems, were collected for the same period.

Regional normalised indexes of the precipitation, air temperature and karst spring discharges were calculated, and different methods were applied to analyse the related time series, including long-term trend analysis using smoothing numerical techniques, cross-correlation and Fourier analysis.

The investigation of the normalised indexes highlighted the existence of long-term complex periodicities, from 2 to more than $30 \mathrm{yr}$, with differences in average values of up to approximately $\pm 30 \%$ for precipitation and karst spring dis-
\end{abstract}

charges, which were both strongly correlated with the winter NAO index.

Although the effects of the North Atlantic Oscillation (NAO) had already been demonstrated in the long-term precipitation and streamflow patterns of different European countries and Mediterranean areas, the results of this study allow for the establishment of a link between a large-scale atmospheric cycle and the groundwater recharge of carbonate karst aquifers. Consequently, the winter NAO index could also be considered as a proxy to forecast the decadal variability of groundwater flow in Mediterranean karst areas.

\section{Introduction}

In the last few decades, the international scientific community has intensely debated climate change on a global scale (WMO, 1979) and the influence of anthropogenic activities. Since 1979, several international research programs (e.g. World Climate Programme - WCP, World Climate Data and Monitoring Programme - WCDMP; http://www.wmo. int/pages/prog/wcp/wcdmp/index_en.php) have been developed to analyse the state of knowledge on climate change, to start global monitoring of the climate systems and to fully understand the causes of its variability. Different groups of international experts (Intergovernmental Panel on Climate Change - IPCC) have been called to analyse the different causes and effects of these changes on the environment. Numerous reports have been published (IPCC, 1990, 2001, 2007) that summarise the current state of climate change and 
evaluate different scenarios for the impact of greenhouse gas pollution on global climate.

On a national scale, many hydrological and climatological studies (Lo Vecchio and Nanni, 1995; Brunetti et al., 2000, 2006), following different methodological approaches, have analysed the decadal climatic variations in Italy and the Mediterranean area with the long-term trends of annual precipitation and mean annual air temperature time series. Other studies in Italy have assessed the relationship between climate change and groundwater circulation (Dragoni and Sukhija, 2008; Cambi and Dragoni, 2000). To assess the impact of the climate variability on the water budget particularly for the Campania region, a reduction of precipitation of approximately $20 \%$ in the last $20 \mathrm{yr}$ was estimated (Ducci and Tranfaglia, 2008).

Numerous studies analysed the influence of the North Atlantic Oscillation (hereafter NAO) (Walker, 1924; Walker and Bliss, 1932) on the annual variability of precipitation in the Northern Hemisphere (Barnston and Livezey, 1987; Hurrell, 1995; Hurrell and van Loon, 1997), particularly in Northern Europe, the Iberian Peninsula and the European Alps (Rodriguez-Puebla et al., 1998; Uvo, 2003; López-Moreno and Vicente-Serrano, 2008; Bartolini et al., 2009; Rodriguez-Puebla and Nieto, 2010), and its impact on river flows in European hydrographic basins (Rimbu et al., 2002; Trigo et al., 2004; López-Moreno et al., 2007; Massei et al., 2009; Morán-Tejeda et al., 2011; Lorenzo-Lacruz et al., 2011).

In the Mediterranean area, a correlation between the NAO, precipitation, river discharges and lake levels was also found in the Middle East and in Turkey (Cullen and deMenocal, 2000; Cullen et al., 2002; Karabörk et al., 2005; Türkes and Erlat, 2005; Kücük et al., 2009). A strong interdependence among the NAO, precipitation, river discharges and air temperature in some southern Italy regions (Brandimarte et al., 2011; Caloiero et al., 2011) was discovered. Recent studies revealed that the impact of the NAO in Mediterranean areas can also be widely conceived as extendable to snow accumulation, crop production, landslides and soil erosivity (Vicente-Serrano and Trigo, 2011). Finally, the NAO was also found to extend its control on climate in northern Africa (Hasanean, 2004) and eastern North America (Sheridan, 2003; Tootle et al., 2005).

The temporal structure of the NAO and periodicities of its impacts on climate have been analysed (Greatbatch, 2000; Wanner et al., 2001; Hurrell et al., 2003), concluding that no preferred time scale of NAO variability exists and a general increase of power with period length in the spectrum of the NAOI. In detail, a quasi-biennial periodicity, a deficit in power from 3 to $5 \mathrm{yr}$ and an increase in power from 8 to $10 \mathrm{yr}$, which was more enhanced in the second half of the 20th century (Hurrell and van Loon, 1997), were recognised. A recent study based on the reconstruction of the NAO since 1650, by means of instrumental and documentary proxy predictors, showed a dominant quasi 60-yr periodicity (Mazzarella and Scafetta, 2012).

None of the abovementioned studies analysed the impact of climatic variability due to the NAO on the aquifer recharge and groundwater regime from the interannual to decadal time scales.

The objective of this study was to examine, on a regional scale, the relationship between the NAO and groundwater recharge by analysing the patterns of an NAO Index (hereafter NAOI), precipitation, air temperature and spring discharge in the Campania region over a multi-decadal period. Datasets covering a period of $90 \mathrm{yr}$ (1921-2010), composed of data gathered from 18 rain gauges and 9 temperature gauges, chosen for their regular functioning during the whole period and their homogeneous distribution over the territory, were elaborated. Additionally, the discharge time series of the Sanità karst spring, fed by the groundwater circulation of an extended fractured and karstified carbonate aquifer, were analysed together with two other shorter time series of karst spring discharges.

The present research represents the continuation and updating of previous studies conducted on the climatic variability of southern Italy due to the NAO (De Vita and Fabbrocino, 2005, 2007). These studies provided a preliminary analysis of regional precipitation and air temperature, having given a first insight into the correlation between the NAO and the decadal variability of groundwater recharge in a test carbonate aquifer.

The paper is organised as follows. After a description of the issue (Sect. 1), the hydrogeological and climate characteristics of the study area are explained (Sect. 2). Subsequently, hydrologic data and methods of analysis (Sect. 3), results (Sect. 4) and concluding remarks are reported (Sect. 5).

\section{Climate and hydrogeological characteristics of the Campania region}

The Campania region is located in the southern part of the Italian Peninsula and has an extension of approximately $13590 \mathrm{~km}^{2}$. It can be subdivided by the fundamental geomorphological features in the Apennine mountain ranges that reach altitudes of 1000 to $2000 \mathrm{~m}$ a.s.l., accounting for $30 \%$ of the total area; coastal plains account for a further $18 \%$, and a remnant part of this region consists of low-altitude hills and alluvial valleys. The climate of the Campania region is of a Mediterranean type with hot dry summers and moderately cool and rainy winters. Mean annual air temperatures are in the range of approximately $10-12^{\circ} \mathrm{C}$ in the mountainous interior, $13-15^{\circ} \mathrm{C}$ in the coastal areas, and $12-13^{\circ} \mathrm{C}$ in the plains surrounded by carbonate mountains. Rainfall regimes vary from the coastal or Mediterranean type to the Apennine sublittoral (Bandini, 1931), which is characterised by a principal maximum in autumn-winter and a minimum 
in the summer. The distribution of precipitation over the region is mainly controlled by the Apennine Mountains, which, acting as a barrier against humid air masses coming from the Tyrrhenian Sea, induce orographic precipitation (HendersonSellers and Robinson, 1986). The lowest mean annual rainfall, approximately 700-900 $\mathrm{mm}$, occurs in the western and eastern parts of the Campania region; the highest mean annual rainfall, approximately $1700-2000 \mathrm{~mm}$, occurs in the central part of the Apennine ridge.

The regional hydrogeological setting (Fig. 1) is essentially characterised by carbonate karst aquifers, with a high degree of permeability due to fracturing and karst. These aquifers, formed by limestone, dolomitic limestone and a dolomitic series of carbonate platform facies (Trias - Paleogene), are confined by aquitards or aquicludes composed of flysch and basinal series (Celico, 1978, 1983; Celico et al., 2000; Allocca et al., 2007, 2009). Morphologically, the first aquifers correspond to the higher mountains (carbonate massifs), while the second ones correspond to the low-altitude hills. Both types of hydrostratigraphic units originate from tectonic units thrust in the Apennines chain. They are typically characterised by a basal groundwater flow, outflowing in huge basal springs, with an average discharge frequently greater than $1.0 \mathrm{~m}^{3} \mathrm{~s}^{-1}$. The patterns of groundwater flow are greatly conditioned both by the altimetry of the boundary with the juxtaposing lower-permeability flysch deposits, as well as by the position and permeability of cataclastic bands associated with main faults and thrusts. The latter, behaving as aquitards, determine the fractioning of the groundwater flow into several groundwater basins. Where the carbonate aquifers are juxtaposed with medium permeable Plio-Quaternary epiclastic and alluvial deposits, a groundwater exchange can exist. A subordinate perched groundwater flow also occurs in the surficial part of karst aquifers, where the different deepening of the epikarst (Celico et al., 2010), as well as stratigraphic and tectonic factors, can generate seasonal and ephemeral springs. The groundwater yield of the Campania's karst aquifers varies from 0.015 to $0.038 \mathrm{~m}^{3} \mathrm{~s}^{-1} \mathrm{~km}^{-2}$ (Allocca et al., 2007, 2009). Given the high quality of their groundwater and their availability for exploitation, basal springs are, for the most part, tapped; thus, carbonate aquifers represent strategic resources for the socio-economic development of the Campania region and southern Italy.

The hydrography of the Campania region is mainly characterised by three principal rivers (Garigliano, Volturno and Sele) and by numerous minor streams, mostly draining towards the Tyrrhenian Sea. The morphology of the drainage network is irregular and controlled by geological and structural features. The principal rivers have a perennial regime in the terminal segments due to the feeding of groundwater that outflows from carbonate aquifers, directly from springs and indirectly through alluvial aquifers. Instead, the streamflow of minor watersheds is frequently ephemeral and more dependent on the precipitation regime.

\section{Hydrologic data and methods of analysis}

Different methods of analysis were applied to investigate decadal variability and correlations among hydrologic time series, including trend analysis using smoothing numerical techniques, cross-correlation and spectrum and crossspectrum analyses through Fourier transform. The trend analysis was performed both with linear regression techniques and with low-pass numerical filtering of time series to provide evidence of their decadal components. In this approach, the moving average over $11 \mathrm{yr}$, centred on the sixth year, was applied, providing a good smoothing of the periodicities shorter than one decade. With the purpose of estimating the variability around the mean value and of recognising anomalous annual values outside the $90 \%$ frequency range, moving 5th and 95th percentiles over $11 \mathrm{yr}$, centred in the sixth year, were calculated.

\subsection{NAO index time series}

Different NAOIs exist depending on the barometric stations and on the period of the year considered (Hurrell et al., 2003). For the case study, the analyses were performed with a subset (1921-2010) of the winter NAOI (December through March mean - DJFM) time series, calculated from the records of the Lisbon (Portugal) and Stikkishlomur (Iceland) barometric stations since 1864 (http://www.cgd.ucar.edu/cas/jhurrell/ indices.html).

\subsection{Precipitation and air temperature time series}

To study the fundamental climatic variables that control groundwater recharge, the total annual precipitation and the mean annual air temperature were gathered from the official monitoring network for the period 1921-2010 (90 yr). Since 2000, the management of the monitoring network was changed from the national technical service and agency (SIMN - Servizio Idrografico Mareografico Nazionale and ISPRA - Istituto Superiore per la Protezione e la Ricerca Ambientale, http://www.isprambiente.gov.it) to the regional Civil Protection agency (http://www.protezionecivile.gov.it). On the basis of the temporal continuity of the record and of the homogeneous distribution over the territory, 18 rain gauge stations were selected. Similarly, 9 thermometric stations were identified (Fig. 1). In this case, the smaller number reflected the sparser density of the monitoring network due to the low spatial variability of air temperature, mostly depending on the altitude.

The assessment of a climate trend at the regional scale was performed by defining the indexes representative of the annual anomalies with respect to the mean value, which minimised variations due to local factors. To obtain such an index for precipitation, the Mean Annual Precipitation Index 


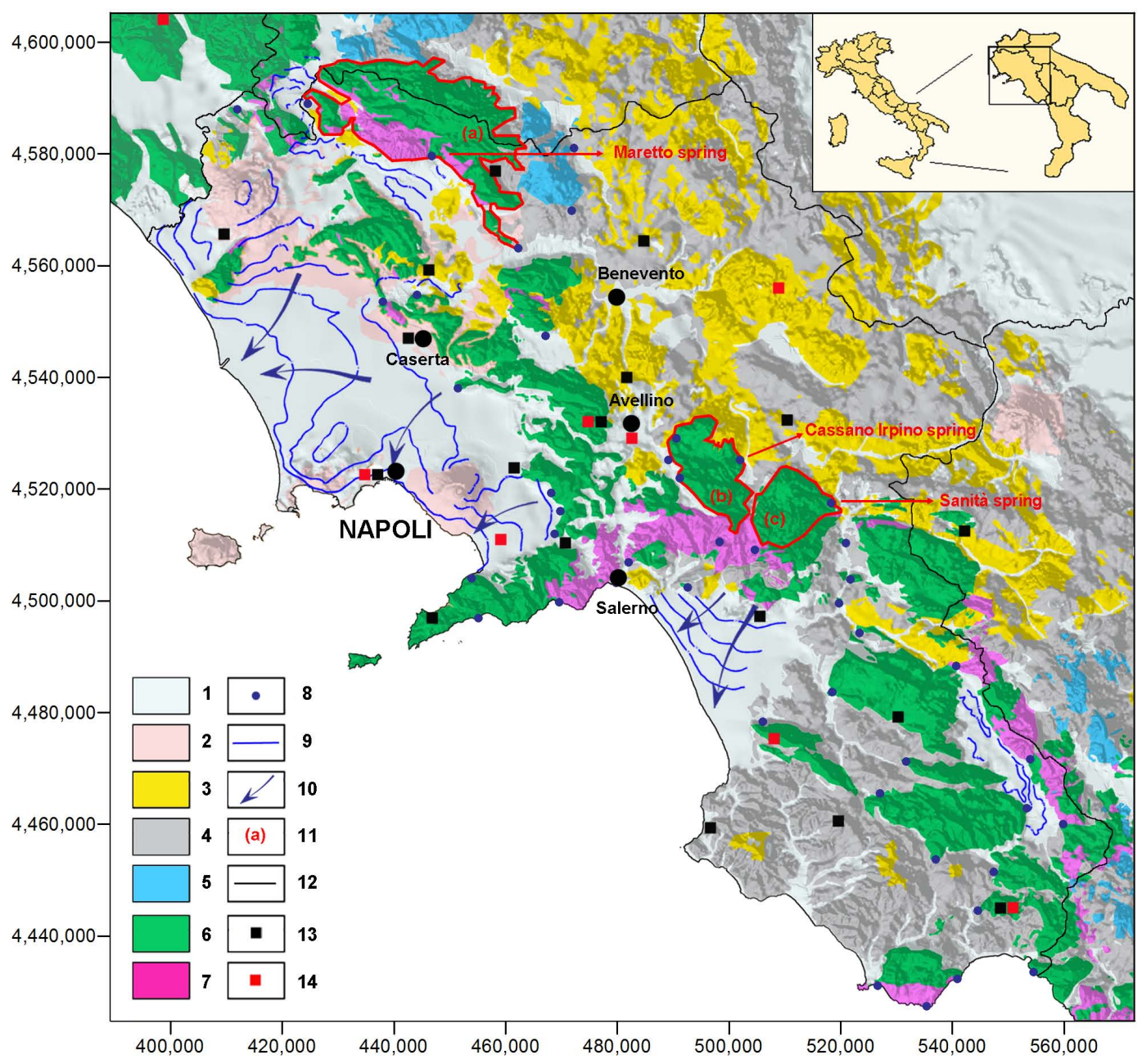

Fig. 1. Hydrogeological map of the Campania region. Hydrostratigraphic units and key to symbols: (1) alluvial and epiclastic units (Quaternary); (2) volcanic units (Pliocene-Quaternary); (3) late orogenic molasses and terrigenous units (Upper Miocene-Pliocene); (4) pre-orogenic and syn-orogenic terrigenous units of inner and thrust-top basins series (Cretaceous-Upper Miocene); (5) siliceous-marly units of outer basin series (Trias-Paleogene); (6) limestone and dolomitic limestone units of carbonate platform series (Jurassic-Paleogene); (7) dolomitic units of carbonate platform series (Trias-Jurassic); (8) main basal springs of carbonate karst aquifers; (9) groundwater head contour lines in alluvial and volcanic aquifers; (10) main preferential drainage axes of groundwater flow in alluvial aquifers; (11) identification of the carbonate karst aquifers analysed: (a) Matese Mount; (b) Terminio Mount; (c) Cervialto Mount; (12) regional boundary; (13) rain gauge stations; (14) air temperature monitoring stations.

(hereafter MAPI) was calculated as follows:

$\mathrm{MAPI}_{i}=\frac{\sum_{j=1}^{18} \frac{\mathrm{AP}_{j i}-\mathrm{MAP}_{j}}{\mathrm{MAP}_{j}}}{\sum_{j=1}^{18} j}$

where $\mathrm{MAPI}_{i}=$ Mean Annual Precipitation Index for the $i$ year (\%); $\mathrm{AP}_{j i}=$ Annual Precipitation for the $j$ rain gauge station and the $i$ year $(\mathrm{mm}) ; \mathrm{MAP}_{j}=$ Mean Annual Precipitation of the whole time series for the $j$ rain gauge station (mm).

Similarly and with reference to the identical observation period (1921-2010), the Mean Annual air Temperature Index (hereafter MATI) was calculated as follows:

$\operatorname{MATI}_{i}=\frac{\sum_{k=1}^{9} \frac{\mathrm{AT}_{k i}-\mathrm{MAT}_{k}}{\mathrm{MAT}_{k}}}{\sum_{k=1}^{9} k}$

where $\operatorname{MATI}_{i}=$ Mean Annual air Temperature Index for the $i$ year (\%); $\mathrm{AT}_{k i}=$ Annual air Temperature for the $k$ air temperature gauge station and the $i$ year $\left({ }^{\circ} \mathrm{C}\right) ; \mathrm{MAT}_{k}=$ Mean Annual air Temperature of the whole time series for the $k$ air temperature gauge station $\left({ }^{\circ} \mathrm{C}\right)$. 


\subsection{Effective precipitation time series}

To assess the mean annual effective precipitation, which regulates groundwater recharge, the mean annual real evapotranspiration for each rain gauge station was estimated by applying the empirical formula of Turc (1954), as several studies have confirmed its reliability for Mediterranean areas and southern Italy (Santoro, 1970; Boni et al., 1982; Celico, 1983):

$\mathrm{ET}_{j i}=\frac{\mathrm{AP}_{j i}}{\sqrt{0.9+\left(\frac{\mathrm{AP}_{j i}}{300+25 \cdot \mathrm{AT}_{j i}+0.05 \cdot \mathrm{AT}_{j i}^{3}}\right)^{2}}}$

where $\mathrm{ET}_{j i}=$ real EvapoTranspiration for the $j$ rain gauge station and the $i$ year $(\mathrm{mm}) ; \mathrm{AP}_{j i}=$ Annual Precipitation for the $j$ rain gauge station and the $i$ year $(\mathrm{mm}) ; \mathrm{AT}_{j i}=$ Annual air Temperature for the $j$ rain gauge station and the $i$ year $\left({ }^{\circ} \mathrm{C}\right)$; for the rain gauge stations without air temperature gauges, mean annual air temperature values were extrapolated using linear correlations with altitude that were statistically robust in all cases.

Finally, for each year of the time series, the Mean Annual Effective Precipitation Index (hereafter MAEPI) was calculated as follows:

$\operatorname{MAEPI}_{i}=\frac{\sum_{j=1}^{18} \frac{\operatorname{AEP}_{j i}-\mathrm{MAEP}_{j}}{\operatorname{MAEP}_{j}}}{\sum_{j=1}^{18} j}$

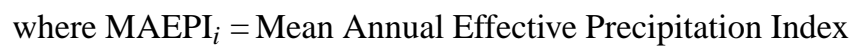
for the $i$ year $(\%) ; \mathrm{AEP}_{j i}=$ Annual Effective Precipitation for the $j$ rain gauge station and the $i$ year (mm); MAEP $_{j}=$ Mean Annual Effective Precipitation of the whole time series for the $j$ rain gauge station $(\mathrm{mm})$.

\subsection{Spring discharge time series}

The discharge time series (1921-2010) of the Sanità karst spring was analysed. This is a unique case for the Campania region and southern Italy, both for its length and for the thorough continuity of the recording, as well as for the hydrogeological representativeness of the feeding aquifer. The Sanità karst spring $\left(15^{\circ} 13^{\prime} 14.8559^{\prime \prime} \mathrm{E}\right.$, $40^{\circ} 49^{\prime} 5.3808^{\prime \prime} \mathrm{N}$; $420 \mathrm{~m}$ a.s.1.) represents the sole groundwater outflow of the Cervialto Mount $\left(15^{\circ} 7^{\prime} 50.4237^{\prime \prime} \mathrm{E}\right.$, $40^{\circ} 46^{\prime} 54.1411^{\prime \prime} \mathrm{N}$; $1808 \mathrm{~m}$ a.s.1.) karst aquifer, which extends for over $128 \mathrm{~km}^{2}$ and is confined by hydrostratigraphic units of the pre-orogenic and syn-orogenic terrigenous basinal series, with a lower degree of permeability (Celico, 1978, 1983). It is located in the upper part of the Sele River watershed (Fig. 1), close to the settlement of Caposele (Province of Avellino). The karst spring was tapped in 1906 by the Apulian Aqueduct (www.aqp.it), which by extension and capa- bility is among the most important works of hydraulic engineering ever made in Italy. The spring discharges have been measured with a bi-weekly frequency until 1964 and daily in the following years, allowing the estimation of the mean annual discharge $\left(3.95 \mathrm{~m}^{3} \mathrm{~s}^{-1}\right)$. The carbonate aquifer suffered strong seismic shaking due to the proximity $(<10 \mathrm{~km})$ of the epicentre of the 23 November 1980 earthquake $(\mathrm{Ms}=6.9$ and a focal depth of $16 \mathrm{~km}$ ) that caused anomalous high spring discharges during the period 1980-1981, followed by a gradual recovery of normal values until 1984 (Celico, 1981; Celico and Mattia, 2002). The same time series was already analysed by other authors in order to discover a method for analysing and forecasting drought periods (Fiorillo, 2009; Fiorillo and Guadagno, 2010).

For this time series, the Mean Annual Discharge Index (hereafter MADI) was calculated as follows:

$\operatorname{MADI}_{i}=\frac{\text { MAD }_{i}-\mathrm{MAD}}{\mathrm{MAD}}$

where $\mathrm{MADI}_{i}=$ Mean Annual Discharge Index for the $i$ year $(\%) ; \mathrm{MAD}_{i}=$ Mean Annual Discharge for the $i$ year $\left(\mathrm{m}^{3} \mathrm{yr}^{-1}\right)$; MAD $=$ Mean Annual Discharge of the whole time series $\left(\mathrm{m}^{3} \mathrm{yr}^{-1}\right)$.

With the same approach, equivalent indexes for the time series of annual maximum and minimum discharges (MADI $_{\max }$ and MADI ${ }_{\min }$ ) were calculated. Due to the dependency of the aqueduct feeding, the latter was considered particularly significant.

Two additional time series of karst spring discharge were chosen among those of greater duration, the Cassano Irpino and Maretto karst springs (Fig. 1), which belong to the Mount Terminio and the Mount Matese karst aquifers, respectively. The recording period under consideration was 1965-2010 for the first time series and 1965-2000 for the second, with an interval partially overlapping that of the Sanità karst spring of 45 and $35 \mathrm{yr}$, respectively.

\section{Results and discussion}

\subsection{Correlation of the NAOI and regional climatic indexes}

The time series of the winter NAOI, MAPI, MATI and MAEPI were first analysed with a least squares linear regression approach (Fig. 2). This analysis showed a general decreasing linear trend for the MAPI and the MAEPI with annual decreasing rates of $-0.13 \%$, with respect to the mean value $(1160.2 \mathrm{~mm})(r=-0.203$; Prob. $\mathrm{t}-$ Student $=5.4 \%)$, for the MAPI and of $-0.26 \%$, with respect to the mean value $(625.2 \mathrm{~mm})(r=-0.196$; Prob. t-Student $=7.2 \%)$ for the MAEPI. In contrast, for the MATI, a more significant linear trend was found with an annual increasing rate of $0.6 \%$, with respect to the mean value of $\left(14.3^{\circ} \mathrm{C}\right)$ $(r=0.262 ;$ Prob. t-Student $=1.5 \%)$. 

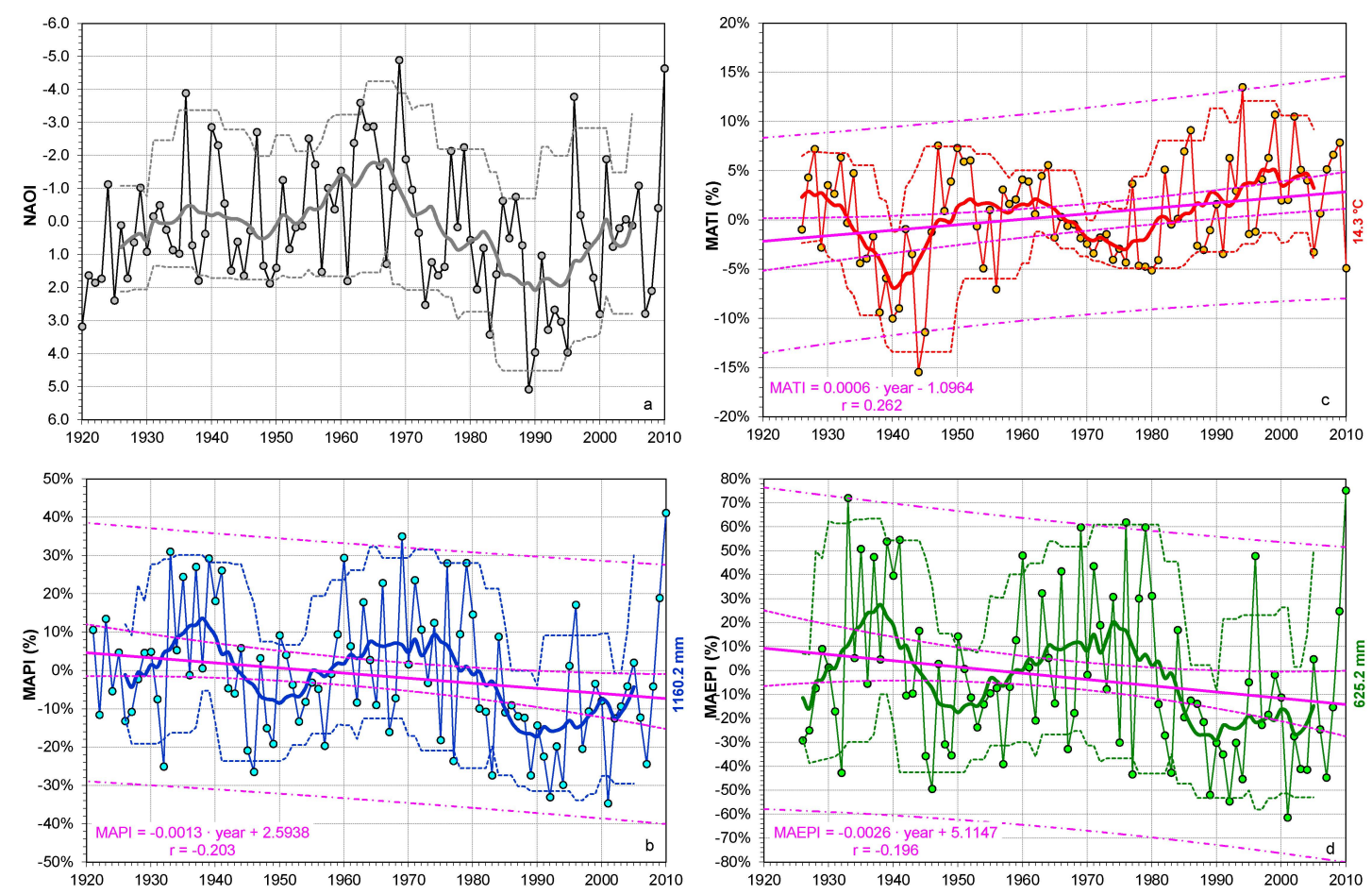

Fig. 2. Time series of (a) winter NAOI time series monitored between Lisbon (Portugal) and Stykkisholmur/Reykjavik (Iceland). (b) MAPI; (c) MATI; (d) MAEPI. Key to symbols: continuous magenta lines = linear trend of the whole time series (equation and coefficient of correlation in the lower left corner); dashed magenta lines $=95 \%$ confidence interval of the expected mean value; dash-dotted magenta lines $=95 \%$ prediction interval of the expected value; continuous thick line $=11-\mathrm{yr}$ moving average centred on the sixth year; dashed lines $=11$-yr moving percentiles of 5th and 95th centred on the sixth year; number on right side of the graphs $=$ absolute mean value of the whole time series.

The long-term declining linear trend over the whole observed time period of the MAPI was in accordance with the findings of other authors for precipitation in southern Italy (Cotecchia et al., 2003; Polemio and Casarano, 2008; Ducci and Tranfaglia, 2008; Brandimarte et al., 2011). In addition, by observing the 11-yr moving average pattern with respect to the normal value (mean value of the whole time series), a complex cyclical dynamic was recognised (Fig. 2b). Two phases characterised by values above the normal value were identified in the periods 1930-1944 and 1958-1978, and three phases below the normal value were identified in the years preceding 1930 and in the periods 1944-1958 and 1980-2005. These long-term fluctuations were found as inversely coincident with those of the winter NAOI (Fig. 2a). Interestingly, for the last part of the time series, an increased frequency of MAPI values below the average value, which were not reached during previous periods, demonstrated a downward shifting trend. From 1985 to 2008, negative values (down to $<-30 \%$ in 1992) were continuously observed, except in 1995, 1996 and 2005. Similar low levels also occurred in the 1930s and the 1940s (1932 and 1946) but with lower frequency (Fig. 2b). The maximum values of the time series were as follows: $+31 \%$ (1933), $+35 \%$ (1969) and $+41 \%$ (2010).
The long-term trend of the MATI (Fig. 2c) displayed an increasing pattern, although a complex cyclical dynamic was also observed in fluctuations of the 11-yr moving average. The minimum value of the MATI was $-15 \%$ (1944), and the maximum was $+14 \%$ (1994). The trends over the last two decades of both the MAPI and the MATI were found to be consistent with what was previously found by other researchers for the Campania region (Ducci and Tranfaglia, 2008).

The long-term trend of the MAEPI (Fig. 2d) showed a decreasing linear trend; however, very remarkable fluctuations around the mean value, with cyclical long-term dynamics, were observed. The extreme values of the time series, ranging from $+72 \%$ (1933) to $-61 \%$ (2001), were identified as matching those of the MAPI time series, therefore demonstrating the amplification effect due to the nonlinear behaviour of the actual evapotranspiration. Similar to the MAPI, a downward shift was observed for the MAEPI in the last decades of the time series.

The variability of the MAPI and the MAEPI, identified as the difference between the 5th and the 95th 11-yr moving percentiles, appeared inconstant during the time series with high ranges (Fig. $2 \mathrm{~b}$ and d) of up to $50 \%$ (from $+30 \%$ to $-20 \%$ ) and $90 \%$ (from $+60 \%$ and $-30 \%$ ), respectively, in the periods characterised by the negative phase of the NAO. 


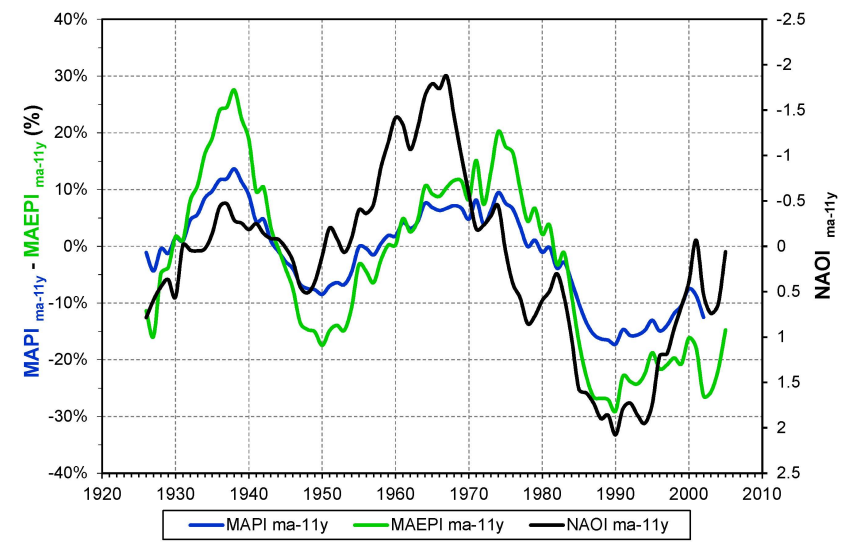

Fig. 3. Comparison of the 11-yr moving averages of the winter NAOI, MAPI, MATI and MAEPI time series for the Campania region.

In contrast, lower variability in the positive phase of the NAO was observed, with ranges of $35 \%$ (from $+5 \%$ to $-30 \%$ ) and $70 \%$ (from $+20 \%$ to $-50 \%$ ), respectively.

The integrated analysis among the different components of the long-term time series of the NAOI, the MAPI and the MAEPI showed, after filtering with the 11-yr moving averages, a strong co-movement and a good overlapping of the positive and negative peaks (Fig. 3). Particularly, the more simplified periodicity of the time series showed two decadal cycles and the beginning of a third cycle starting at approximately 1990 .

A significant correlation between the winter NAOI and the MAPI was verified using a cross-correlation analysis performed with the raw data of these two time series. In this case, the absolute maximum value of the correlation $(r=-0.422$; Prob. t-Student $<0.1 \%)$ was found at a lag time variable from 0 to $+1 \mathrm{yr}$ (Fig. 4). Considering the 11-yr moving average time series, the absolute maximum value of the resulting correlation increased $(r=-0.767$; Prob. t-Student $<0.1 \%)$. The cross-correlation analysis between the winter NAOI and the MAEPI (Fig. 5) revealed a stronger correlation for the raw data of the time series $(r=-0.431$; Prob. t-Student $<0.1 \%)$.

\subsection{Correlation of the NAOI and spring discharges}

A general linear decreasing trend with a rate of $-0.14 \%$ per year, with respect to the mean value $\left(3.95 \mathrm{~m}^{3} \mathrm{~s}^{-1}\right)$ $(r=-0.300$; Prob. t-Student $=0.5 \%)$, and high annual fluctuations around the mean, with extremes of $+38 \%$ (1941) and $-25 \%$ (2002), were found for the MADI time series (Fig. 6a). Specifically, a complex multi-year cyclicality was identified by the 11-yr moving average, which showed two phases of maxima corresponding to the years 1930-1944 and 1958-1978 and two phases of minima corresponding to the years before 1930, the period 1944-1958 and the years after
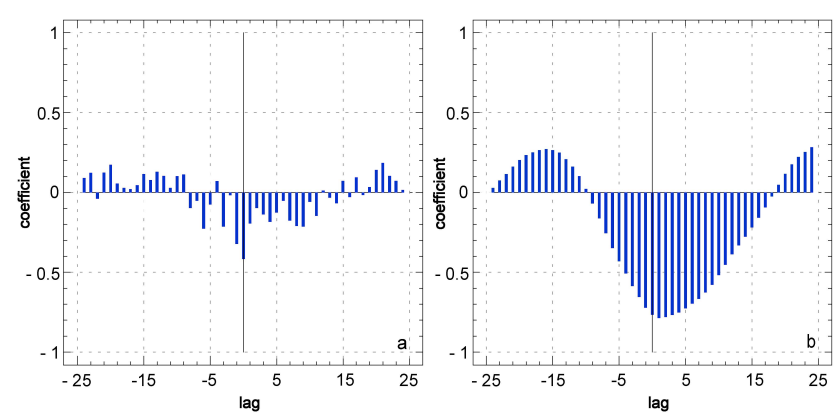

Fig. 4. Cross-correlation analysis between the winter NAOI and the MAPI carried out on (a) the original time series and (b) the 11-yr moving average time series.
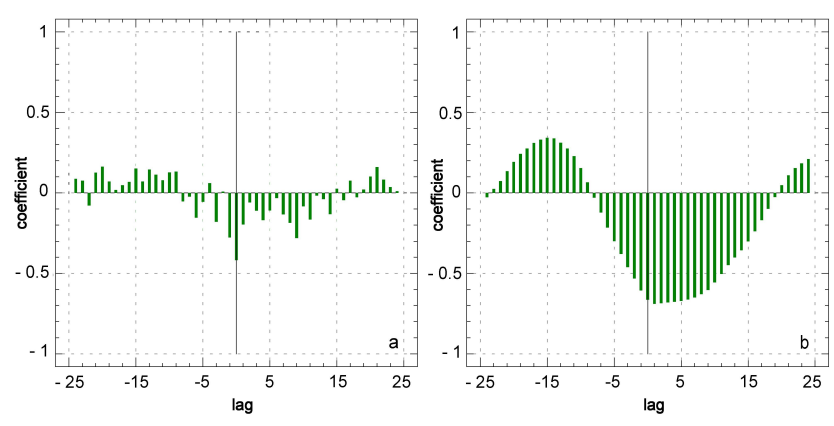

Fig. 5. Cross-correlation analysis between the long-term components of the winter NAOI and the MAEPI carried out on (a) the original time series data and (b) the 11-yr moving average.

1980 (Fig. 8a and b). The variability of the MADI, identified as the difference between the 5th and the 95th 11-yr moving percentiles, was observed to be higher in the negative phase of the NAO, with a range of $45 \%$ (from $+30 \%$ and $-15 \%$ ), and lower in the positive phase of the NAO, with a range of $25 \%$ (from $+5 \%$ and $-20 \%$ ) (Fig. 6a). In contrast, for the $\mathrm{MADI}_{\min }$ time series, a lower variability was recognised (Fig. 6b).

The integrated analysis of the long-term components of the winter NAOI and MADI time series, expressed by the 11-yr moving averages, showed a phase coherence (Fig. 7), except for the period 1980-1981, which was influenced by the earthquake shaking. This observation was confirmed by the analysis of cross-correlation (Fig. 8), carried out both on the raw data of the time series $(r=-0.506$; Prob. t-Student $<0.1 \%)$ and for the 11-yr moving averages $(r=-0.780$; Prob. tStudent $<0.1 \%$ ). The maximum correlation was found for both at lag times of 0 and $+1 \mathrm{yr}$.

The comparison of the discharge time series of the Sanità karst spring with two other time series of spring discharge belonging to the Cassano Irpino and Maretto karst springs, even if for a limited overlapping period (1965-2010 and 1965-2000) (Fig. 9), permitted the recognition of a coherent descending pattern until 1990 and a rising trend in the 

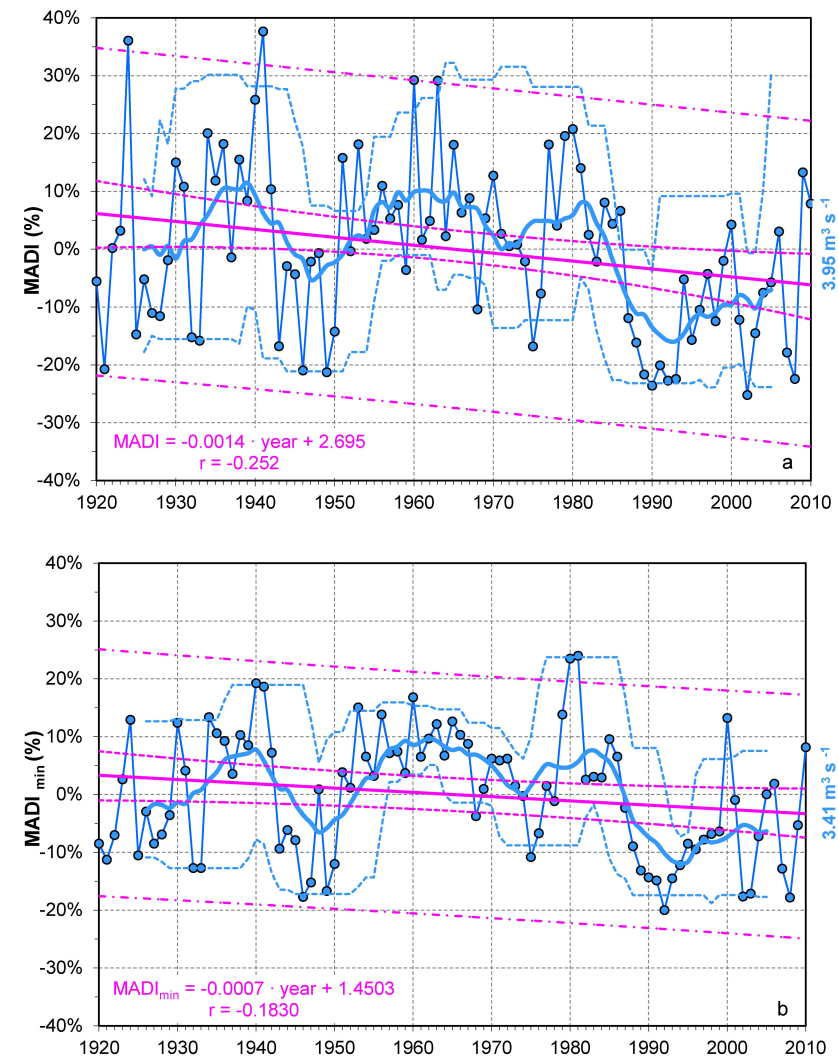

Fig. 6. (a) MADI time series; (b) $\mathrm{MADI}_{\min }$ time series. Key to symbols: continuous magenta line $=$ linear trend of the whole time series (equation and coefficient of correlation in the lower left corner); dashed magenta lines $=95 \%$ confidence interval of the expected mean value; dash-dotted magenta lines $=95 \%$ prediction interval of the expected value; continuous thick line $=11-\mathrm{yr}$ moving average centred on the sixth year; dashed lines $=11-\mathrm{yr}$ moving percentiles of 5th and 95th centred on the sixth year; number on right side of the graphs $=$ absolute mean value of the whole time series .

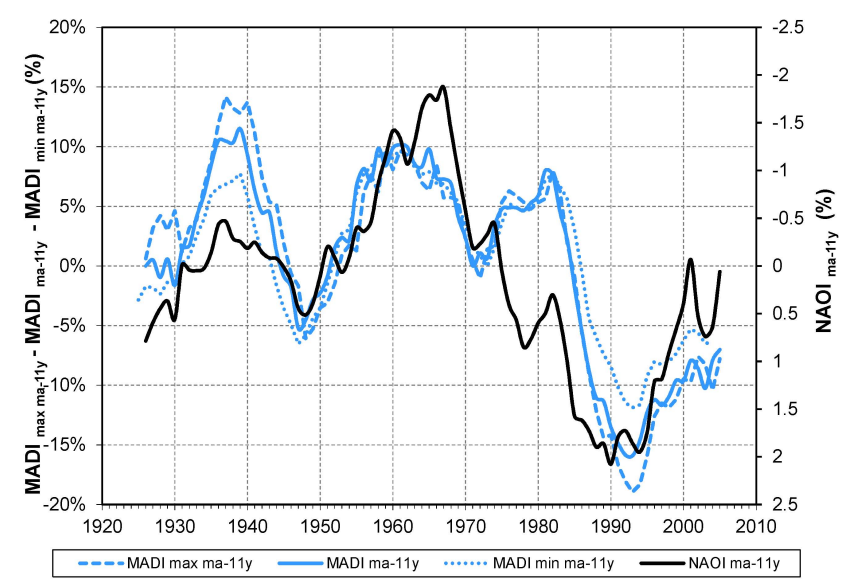

Fig. 7. Comparison between the 11-yr moving averages of the NAOI time series and the MADI $I_{\max }$, MADI and MADI $\mathrm{min}_{\text {in }}$ time series of the Sanità spring.
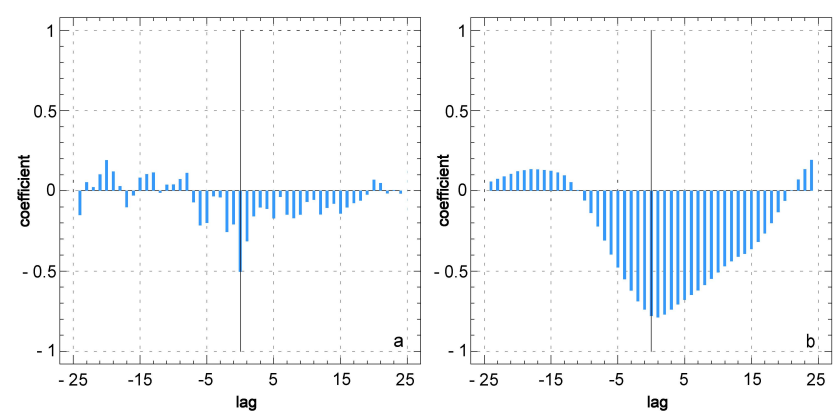

Fig. 8. Cross-correlation analysis between the NAOI and the MADI, carried out on (a) the original time series and (b) the 11-yr moving averages.

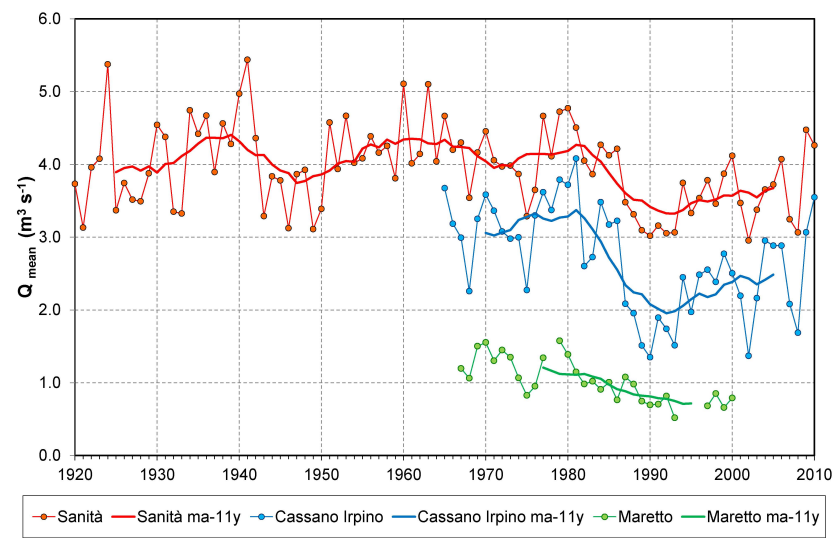

Fig. 9. Graphical comparison of annual mean discharges $\left(Q_{\text {mean }}\right)$ of the Sanità, Cassano Irpino and Maretto karst springs (Fig. 1). Key to symbol: continuous thick line $=11-\mathrm{yr}$ moving average centred on the sixth year.

following years, according to the pattern of the NAOI for the same period (Fig. 2a).

\subsection{Cross-spectrum analysis of the NAOI, the MAPI and the MADI}

A Fourier analysis was applied to the NAOI, MAPI and MADI time series in order to understand their temporal structures, periodicities and respective coherency. The purpose of this analysis is to decompose complex time series with cyclical components into fundamental underlying sinusoidal functions (sine and cosine), finding their amplitudes and wavelengths and reconstructing their power spectra.

The observed spectrum for the winter NAOI results were similar to that previously observed by other authors (Sect. 1), with principal periodogram peaks characterised by periodicities from 2 to $3 \mathrm{yr}$, from 5 to $9 \mathrm{yr}$, and at 30 and $45 \mathrm{yr}$ (Fig. 10). Due to the length of the time series, longer periodicities were not found. The principal periodogram peaks for the MAPI and MADI time series were simultaneously observed at 2, 5, 15, 22 and $45 \mathrm{yr}$ and appeared to match those 


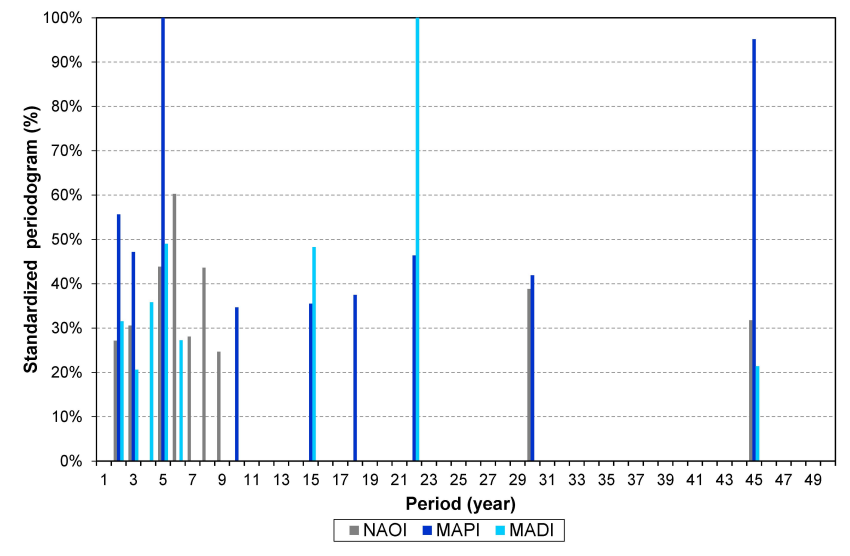

Fig. 10. Largest periodogram peaks for the NAOI, MAPI and MADI time series.

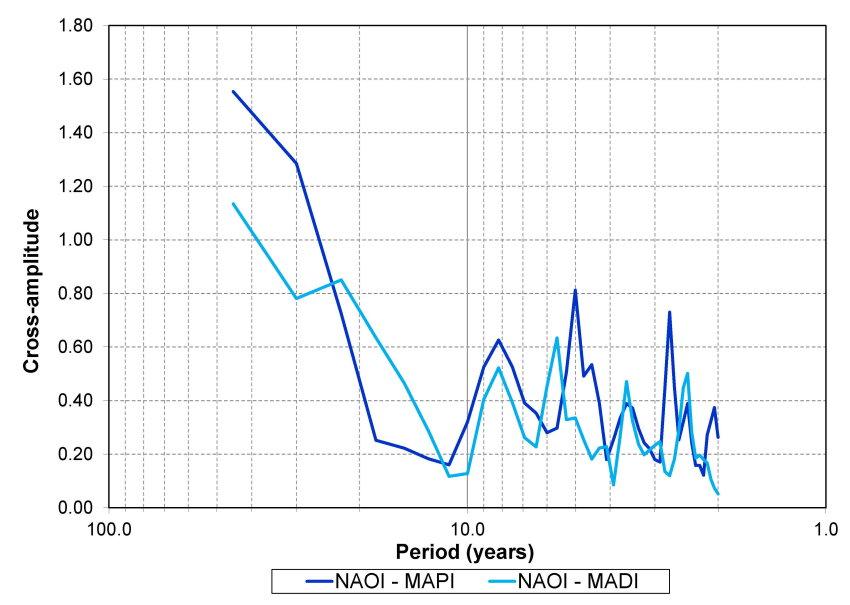

Fig. 11. Cross-amplitude of the MAPI and MADI time series compared to the NAOI time series.

belonging to the winter NAOI for periodicities from 2 to $3 \mathrm{yr}$, at $5 \mathrm{yr}$ and at $45 \mathrm{yr}$ (Fig. 10).

To find periodicities of the MAPI and the MADI that were synchronous with the winter NAOI, a cross-spectral analysis (Shumway and Stoffer, 2006) was performed to obtain cross-amplitude values of the cross periodogram, corresponding to a measure of the covariance between the respective frequency components in the two time series.

From this analysis (Fig. 11), correlations for periodicities from 2 to $3 \mathrm{yr}$, from 3 to $4 \mathrm{yr}$, for periods of around $5 \mathrm{yr}$ and $8 \mathrm{yr}$ and for periods from 30 to $45 \mathrm{yr}$ were discovered. The longer periodicities, which were characterised by the greatest cross-amplitude, were also recognised by the observation of the fluctuation of the 11-yr moving averages, whose minima peaks occurred simultaneously for the three time series after approximately 45 yr (Figs. 4 and 9).

\section{Conclusions}

In the Campania region, a complex cyclical periodicity of rainfall patterns that was mainly teleconnected with the North Atlantic Oscillation was discovered, confirming that previously observed for other regions of western Europe and North America (Hurrell and van Loon, 1997; VincenteSerrano and Trigo, 2011). The integrated analyses of regional indexes of precipitation, air temperature and effective precipitation in the period 1921-2010 (90 yr) revealed a significant impact of the NAO on processes of groundwater recharge. This was confirmed by the robust correlation between the winter NAO index and the annual spring discharges of a unique long-lasting karst spring discharge time series, as well as of other shorter time series.

The analysis of the temporal structure of the time series showed stronger correlations for periodicities varying from the interannual to decadal time scales, with the greatest correlation at the periodicity from 30 to $45 \mathrm{yr}$. This periodicity determined a decadal variability of the precipitation and spring discharge, configuring two complete long-term cycles with minima corresponding to 1925, 1948 and 1990 and displaying a new cycle starting in the early 1990s. The latter has been characterised by an increase in precipitation and the spring discharges as well as by the rising of piezometric levels and the return of karst springs, which disappeared during the 1980s and 1990s.

The results obtained can be considered a first attempt to extend understanding of the impact of the NAO on the hydrological variability over Europe and Mediterranean karst areas, including the underground component of the hydrological cycle on large and strategic regional aquifers. Moreover, the correlations can be conceived as a basis in formulating groundwater recharge models of carbonate karst aquifers and in planning appropriate management scenarios of aqueduct feeding from the interannual to the decadal time scales. Due to this teleconnection, the NAO would be conceived as a proxy to forecast climate change (Mazzarella and Scafetta, 2012) the decadal variability of groundwater recharge in Mediterranean karst areas. This consideration is enhanced by the wide interest of the scientific community in the North Atlantic Oscillation, which continuously operates, monitoring and interpretations of this large-scale atmospheric phenomenon.

Acknowledgements. The authors wish to thank Gerardo Ventafridda of the AQP Aquedotto Pugliese S.p.A. (http: //www.aqp.it) who provided data for the Cassano Irpino and the Sanità karst springs. The authors are also grateful to the Department of Civil Protection of the Campania region (http://www.regione.campania.it), which has kindly provided the rainfall and temperature data. Finally, the authors are grateful to anonymous reviewers for constructive criticism.

Edited by: N. Romano 


\section{References}

Allocca, V., Celico, F., Celico, P., De Vita, P., Fabbrocino, S., Mattia, S., Monacelli, G., Musilli, I., Piscopo, V., Scalise, A. R., Summa, G., and Tranfaglia, G.: Illustrative Notes of the Hydrogeological Map of Southern Italy, Istituto Poligrafico e Zecca dello Stato, ISBN 88-448-0215-5, 1-211, 2007.

Allocca, V., Celico, F., Celico, P., De Vita, P., Fabbrocino, S., Mattia, C., Monacelli, G., Musilli, I., Piscopo, V., Scalise, A. R., Summa, G., and Tranfaglia, G.: La carta idrogeologica dell'Italia meridionale. Metodi ed analisi territoriali per l'identificazione e la caratterizzazione dei corpi idrici sotterranei (Direttiva 2000/60/CE), L'ACQUA, 4, 21-32, 2009 (in Italian).

Bandini, A.: Tipi pluviometrici dominanti sulle regioni italiane, Il Servizio Idrografico Italiano. Ministero dei Lavori Pubblici, Roma, 1931 (in Italian).

Barnston, A. G. and Livezey, R. E.: Classification, Seasonality, and Persistence of Low-Frequency Atmospheric Circulation Patterns, Mon. Weather Rev., 115, 1083-1126, 1987.

Bartolini, E., Claps, P., and D'Odorico, P.: Interannual variability of winter precipitation in the European Alps: relations with the North Atlantic Oscillation, Hydrol. Earth Syst. Sci., 13, 17-25, doi:10.5194/hess-13-17-2009, 2009.

Boni, C., Bono, P., and Capelli, G.: Valutazione quantitativa dell'infiltrazione efficace in un bacino dell'Italia centrale: confronto con analoghi bacini rappresentativi di diversa litologia, Geologia Applicata e Idrogeologia, 17, 437-452, 1982.

Brandimarte, L., Di Baldassarre, G., Bruni, G., D’Odorico, P., and Montanari, A.: Relation Between the North-Atlantic Oscillation and Hydroclimatic Conditions in Mediterranean Areas, Water Resour. Manage., 25, 1269-1279, 2011.

Brunetti, M., Maugeri, M., and Nanni, T.: Variations of temperature and precipitation in Italy from 1866-1995, Theor. Appl. Climatol., 65, 165-174, 2000.

Brunetti, M., Maugeri, M., Monti, F., and Nanni, T.: Temperature and precipitation variability in Italy in the last two centuries from homogenized instrumental time series, Int. J. Climatol., 26, 345381, 2006.

Caloiero, T., Coscarelli, R., Ferrari, E., and Mancini, M.: Precipitation change in Southern Italy linked to global scale oscillation indexes, Nat. Hazards Earth Syst. Sci., 11, 1683-1694, doi:10.5194/nhess-11-1683-2011, 2011.

Cambi, C. and Dragoni, W.: Groundwater, recharge variability and climatic changes: some consideration out of the modeling of an Apenninic spring, Hydrogeology, 4, 11-25, 2000.

Celico, F. and Mattia, C.: Analisi degli effetti indotti dal sisma del 23/11/1980 sugli equilibri idrogeologici della sorgente Sanità (Campania), mediante simulazione ragionata delle dinamiche di ricarica e esaurimento, Quaderni di Geologia Applicata, 1, 5-18, 2002 (in Italian).

Celico, F., Celico, P., De Vita, P., and Piscopo, V.: Groundwater flow and protection in the Southern Apennines (Italy), Hydrogéologie, 4, 39-47, 2000.

Celico, F., Naclerio, G., Bucci, A., Nerone, V., Capuano, P., Carcione, M., Allocca, V., and Celico, P.: Influence of pyroclastic soil on epikarst formation: a test study in southern Italy, Terra Nova, 22, 110-115, 2010.

Celico, P.: Schema idrogeologico dell'Appennino carbonatico centro-meridonale, Memorie e Note Istituto di Geologia Applicata, Napoli, 14, 1-97, 1978 (in Italian).
Celico, P.: Relazioni tra idrodinamica sotterranea e terremoti in Irpinia (Campania), Rendiconti Società Geologica Italiana, 4, 103 108, 1981 (in Italian).

Celico, P.: Idrogeologia dei massicci carbonatici, delle piane quaternarie e delle aree vulcaniche dell'Italia centro-meridionale (Marche e Lazio meridionale, Abruzzo, Molise e Campania), Quaderni della Cassa per il Mezzogiorno, 4/2, 1-203, 1983.

Cotecchia, V., Casarano, D., and Polemio, M.: Piovosità e siccità in Italia meridionale tra il 1821 ed il 2001, L'ACQUA, 2, 99-106, 2003 (in Italian).

Cullen, H. M. and deMenocal, P. B.: North Atlantic Influence on Tigris-Euphrates streamflow, Int. J. Climatol., 20, 853-863, 2000.

Cullen, H. M., Kaplan, A., Arkin, P. A., and deMenocal, P. B.: Impact of the North Atlantic Influence on the middle eastern climate and streamflow, Climatic Change, 55, 315-338, 2002.

De Vita, P. and Fabbrocino, S.: L'oscillazione del Nord Atlantico e la variabilità pluriennale delle risorse idriche sotterranee negli acquiferi carbonatici dell'Italia meridionale, Giornale di Geologia Applicata, 2, 357-362, 2005 (in Italian).

De Vita, P. and Fabbrocino, S.: Influence of the North Atlantic Oscillation on the climatic variability and groundwater resources in carbonate aquifers of Southern Italy, Italian Journal of Engineering Geology and Environment, 1, 33-48, 2007.

Dragoni, W. and Sukhija, B. S.: Climate change and groundwater: a short review, Geological Society, London, Special Publications, 288, 1-12, 2008.

Ducci, D. and Tranfaglia, G.: The Effect of Climate Change on the Hydrogeological Resources in Campania Region - Italy, in: Groundwater and climatic changes, edited by: Dragoni, W., Geological Society, London, Special Publications, 288, 25-38, 2008.

Fiorillo, F.: Spring hydrographs as indicators of droughts in a karst environment, J. Hydrol., 373, 290-301, 2009.

Fiorillo, F. and Guadagno, F. M.: Karst Spring Discharges Analysis in Relation to Drought Periods, Using the SPI, Water Resour. Manage., 24, 1867-1884, 2010.

Greatbatch, R. J.: The North Atlantic Oscillation, Stoch. Env. Res. Risk A., 14, 213-242, 2000.

Hasanean, H. M.: Wintertime surface temperature in Egypt in relation to the associated atmospheric circulation, Int. J. Climatol., 24, 985-999, 2004.

Henderson-Sellers, A. and Robinson, P. J.: Contemporary Climatology, John Wiley \& Sons, New York, 1986.

Hurrell, J. W.: Decadal Trends in the North Atlantic Oscillation: Regional Temperatures and Precipitation, Science, 269, 676-679, 1995.

Hurrell, J. W. and van Loon, H.: Decadal variations in climate associated with the North Atlantic Oscillation, Climatic Change, 36, 301-326, 1997.

Hurrell, J. W., Kushirn, Y., Ottersen, G., and Visbeck, N.: An Overview of the North Atlantic Oscillation, in: The North Atlantic Oscillation: Climatic Significance and Environmental Impact, Geophysical Monograph, American Geophysical Union, 134, doi:10.1029/134GM01, 2003.

IPCC: Climate Change, The IPPC Scientific Assessment, edited by: Houghton, J. T., Jenkins, G. J., and Ephraums, J. J., ISBN 052140360X, 1-414, Cambridge University Press, UK, 1990.

IPCC: The scientific basis. Contribution of working group I to the third assessment report of the Intergovernmental Panel on 
Climate Change (ICCP), edited by: Houghton, J. T., Ding, Y., Griggs, D. J., Noguer, M., Van der Linden, P. J., and Xiaosu, D., Cambridge University Press, UK, 2001.

IPCC: Climate Change, Synthesis Report. Contribution of Working Groups I, II and III to the Fourth Assessment Report of the Intergovernmental Panel on Climate Change, edited by: Pachauri, R. K. and Reisinger, A., Geneva, Switzerland, 1-104, 2007, available at: http://www.ipcc.ch/publications_and_data/publications_ ipcc_fourth_assessment_report_synthesis_report.htm, 2007.

Karabörk, M. C., Kahya, E., and Karaca, M.: The influences of the Southern and North Atlantic Oscillation on climatic surface variables in Turkey, Hydrolog. Process., 19, 1185-1211, 2005.

Kücük, M., Kahya, E., Cengiz, T. M., and Karaca, M.: North Atlantic Oscillation influences on Turkish lake levels, Hydrolog. Process., 23, 893-906, 2009.

López-Moreno, J. I. and Vicente-Serrano, S. M.: Positive and negtive Phases of the Winter-time North Atlantic Oscillation and Drought occurrence over Europe: multitemporal-scale approach, J. Climate, 21, 1220-1241, 2008.

López-Moreno, J. I., Beguería, S., Vicente-Serrano, S. M., and García-Ruiz, J. M.: Influence of the North Atlantic Oscillation on water resources in central Iberia: Precipitation, stream-flow anomalies, and reservoir management strategies, Water Resour. Res., 43, W09411, doi:10.1029/2007WR005864, 2007.

Lorenzo-Lacruz, J., Vicente-Serrano, S. M., López-Moreno, J. I., González-Hidalgo, J. C., and Morán-Tejeda, E.: The response of Iberian rivers to the North Atlantic Oscillation, Hydrol. Earth Syst. Sci., 15, 2581-2597, doi:10.5194/hess-15-25812011, 2011.

Lo Vecchio, G. and Nanni, T.: The variation of the atmospheric temperature in Italy during the last hundred years and its relationship with solar output, Theor. Appl. Climatol., 51, 159-146, 1995.

Massei, N., Laignel, B., Deloffre, J., Mesquita, J., Motelay, A., Lafite, R., and Durand, A.: Long-term hydrological changes of the Seine River flow (France) and their relation to the North Atlantic Oscillation over the period 1950-2008, Int. J. Climatol., 30, 2146-2154, 2009.

Mazzarella, A. and Scafetta, N.: Evidences for a quasi 60-year North Atlantic Oscillation since 1700 and its meaning for global climate change, Theor. Appl. Climatol., 107, 599-609, 2012.

Morán-Tejeda, E., López-Moreno, I., Ceballos-Barbancho, A., and Vicente-Serrano, S. M.: Evaluating Duero's basin (Spain) response to the NAO phases: spatial and seasonal variability, Hydrolog. Process., 25, 1313-1326, 2011.

Polemio, M. and Casarano, D.: Climate change, drought and groundwater availability in Southern Italy, Geological Society, London, Special Publications, 288, 39-51, 2008.

Rimbu, N., Boroneant, C., Buta, C., and Dima, M.: Decadal variability of the Danube river flow in the lower basin and its relation with the North Atlantic Oscillation, Int. J. Climatol., 22, 11691179, 2002.
Rodriguez-Puebla, C. and Nieto, S.: Trends of precipitation over the Iberian Peninsula and the North Atlantic Oscillation under climate change conditions, Int. J. Climatol., 30, 1807-1815, 2010.

Rodriguez-Puebla, C., Encinas, A. H., Nieto, S., and Garmendia, J.: Spatial and temporal patterns of annual precipitation variability over the Iberian Peninsula, Int. J. Climatol., 18, 299-316, 1998.

Santoro, M.: Sulla applicabilità della formula di Turc per il calcolo della evapotraspirazione effettiva in Sicilia, Proceedings I International Conference on Groundwater, I.A.H., Palermo, 1970 (in Italian).

Sheridan, S. C.: North American weather-type frequency and teleconnection indices, Int. J. Climatol., 23, 27-45, 2003.

Shumway, R. H. and Stoffer, D. S.: Time Series Analysis and its Application (2 Edn.), Springer, 1-588, 2006.

Tootle, G., Piechota, T., and Singh, A.: Coupled oceanicatmospheric variability and U. S. streamflow, Water Resour. Res., 41, 1-11, 2005.

Trigo, R. M., Pozo-Vázquez, D., Osborn, T. J., Castro-Díez, Y., Gámiz-Fortis, S., and Esteban-Parra, M. J.: North Atlantic Oscillation influence on precipitation, river flow and water resources in the Iberian Peninsula, Int. J. Climatol., 24, 925-944, 2004.

Turc, L.: Le bilan d'eau des sols: relations entre les précipitations, l'évaporation et l'éecolument, Annales agronomiques, Paris, 5, 491-595, 1954 (in French).

Türkes, M. and Erlat, E.: Climatological responses of winter precipitation in Turkey to variability of the North Atlantic Oscillation during the period 1930-2001, Theor. Appl. Climatol., 81, 45-69, 2005.

Uvo, C.: Analysis and regionalization of northern European winter precipitation based on its relationship with the North Atlantic Oscillation, Int. J. Climatol., 23, 1185-1194, 2003.

Vicente-Serrano, S. M. and Trigo, R. M. (Eds.): Hydrological, Socioeconomic and Ecological Impacts of the North Atlantic Oscillation in the Mediterranean Region (Advances in Global Change Research), Springer, 1-236, 2011.

Walker, G. T.: Correlation in seasonal variation of weather, IX Memories of the Indian Meteorological Department, 24, 275332, 1924.

Walker, G. T. and Bliss, E. W.: World Weather V, Memories of the Royal Meteorological Society, 4, 53-84, 1932.

Wanner, H., Brönnimann, S., Casty, C., Gyalistras, D., Luterbacher, J., Schmutz, C., Stephenson, D. B., and Xoplaki, E.: North Atlantic Oscillation - concepts and studies, Survey Geophysics Journal, 22, 321-381, 2001.

WMO: World Climate Conference, WMO, No. 537, ISBN 92-6310537-5. Proceedings of the World Climate Conference, Geneva, Switzerland, 12-23 February 1979. 